matter in sea water from all depths of the oceans is not attacked by bacteria under natural conditions, it will be attacked as soon as the water is enclosed in bottles, presumably because of the presence of the inner surfaces of the bottles. According to experiments by, for example, Waksman and Renn", the oxygen consumption found by Riley is easily explained as being due to respiration of bacteria while the water was in the bottles. The position is different, however, as regards 'oxygen production', that is, the difference in content of oxygen in light and dark bottles. Riley takes it for granted that this difference is due to the photosynthetic activity of the phytoplankton. In all probability it is, however, simply due to the bactericidal effect of the sunlight. It is a well-known fact that sunlight is highly effective for killing bacteria. It is not only the ultra-violet rays which are active; the light not absorbed by glass is also effective. Therefore it is quite natural that the consumption of oxygen in the illuminated bottles should be lower than that in those kept in the dark.

The investigations on the Galathea by means of the carbon-14 method give evidence that the order of magnitude for the production of organic matter in Riley's experiments is wrong. Let us compare the Sargasso Sea with the tropical western part of the Indian Ocean, where the amount of plankton at any rate is not smaller than that in the Sargasso Sea. In surface water from six stations (265-274, see chart) the average assimilation of carbon was found to be $0.15 \mathrm{mgm}$. per hour and cu. m. at 18,000 lux. If the samples, as in the case of Riley's experiments, had been placed in full sunlight during the whole day, we should, according to experience on the Galathea, have found a daily assimilation of carbon of $0.15 \times 12 \times 0.6=1.08 \mathrm{mgm}$. per cu. m. According to Riley, an average of $26 \mathrm{mgm}$. carbon per cu. m. (corresponding to $0.07 \mathrm{mgm}$. oxygen/litre) was 'assimilated' daily in the Sargasso Sea. On an average, thus, only 4 per cent of what Riley 'found' in the Sargasso Sea was found in the Indian Ocean.

As an example of the investigations on the Galathea Expedition, the production of matter in milligrams of carbon assimilated per day and sq. $m$. is given for a section across the Indian Ocean in the accompanying chart.

On the basis of all material obtained on the Galathea Expedition, an average annual gross pro-

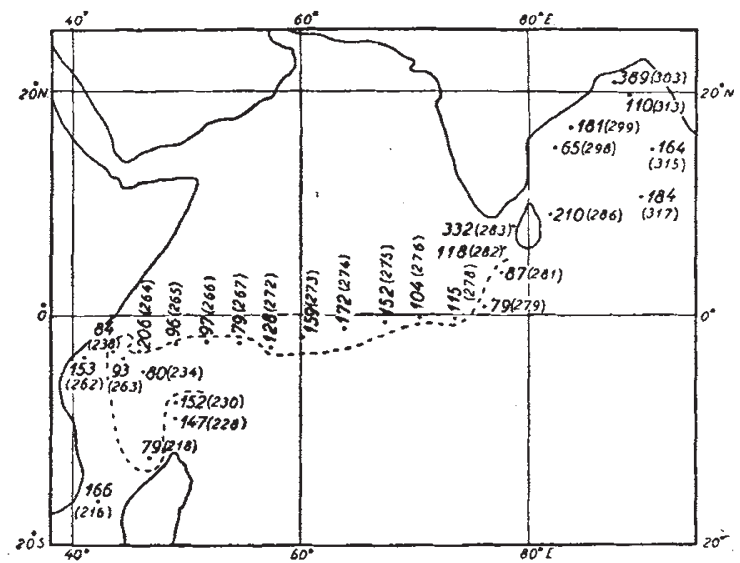

Production of organic matter in mga. per day per sq. m. In the Indian Ocean. Station numbers in brackets duction of matter corresponding to $45 \mathrm{gm}$. assimilated carbon per sq. m. would seem probable. If we reckon on an area of sea of $361 \times 10^{8}$ sq. $\mathrm{km}$., we obtain a total fixation of carbon per year in the sea of $1.6 \times$ $10^{10}$ tons. This is nearly the same as the $1.9 \times 10^{10}$ tons carbon which, according to Schroeder, are fixed on land. If, furthermore, we allow for a loss of 25 per cent through respiration, the total net production in the sea per year corresponds to $1.2 \times 10^{10}$ tons carbon.

There are considerable variations in the productivity of the different areas of the oceans. The tropical parts are often - but far from always-relatively poor.

[March 17.

${ }^{1}$ Steemann Nielsen, E., Nature, 167, 684 (1951).

2 Steemann Nielsen, E., J. Cons. Int. Explor. Mer., 18, No. 2 (1952).

${ }^{3}$ Rabinowitch, E. I., "Photosynthesis and Related Processes", 1 (New York, 1915).

4 Schroeder, H., Naturwiss., 7, 8 (1919).

${ }_{5}$ Riley, G. A., Bull. Bingham Oceanographic Coll., 7, 3 (1941).

Seiwell, H. R., J. Cons. Int. Explor. Mer., 10, 20 (1935).

'Riley, G. A., J. Mar. Res., 1, 335 (1939).

${ }^{8}$ Redfleld, A., Pap. in Phys. Oceanog. and Met., Mass. Inst. Technol.

Waksman, S. A., and Renn, C. E., Biol. Bull., 70, 472 (1936).

\section{UNIVERSITY EDUCATION IN DUNDEE}

THE Royal Commission on University Education in Dundee, the report of which has now appeared*, was appointed in May 1951, with Lord Tedder as chairman, in view of the failure of Lord Cooper's report, published in August 1949, to lead to any negotiated settlement of the controversy over the organization of university education in Dundee and the relations between the University of St. Andrews and University College, Dundee, which has been going on intermittently for more than sixty years. Although Lord Cooper's suggested solution of the problems involved was not implemented, it was decided that the dispute must be ended by parliamentary settlement, and the Royal Commission was appointed to prescribe in detail the necessary steps to be taken and the changes, if any, which would be required in the constitution, functions and powers of the University of St. Andrews, University College, Dundee, or of any other institution concerned. The situation was altered to some extent by Lord Cooper's report itself, and fresh urgency was given to the problem, both by the concern of the University Grants Committee over the impossibility, under existing conditions, of estimating the expenditure required for the quinquennium commencing in 1952-53, and also by the detrimental effect of continued indecision and hostility on the academic reputation of the University of St. Andrews, and particularly on its departments in Dundee.

The Cooper Report considerably lightened the task of the Royal Commission, and the majority of the Commission's most important conclusions do not seriously conflict with those of Lord Cooper; but the new survey is based on as fully searching an inquiry. For this complex and difficult situation local feelings are responsible as well as the completely different system of government of University College,

- Royal Commission on University Education in Dundee, 1951-52 Report. (Cmd. 8514.) Pp. 75. (London: H.M. Stationery Office, 1952.) 28. 6d. net. 
Dundee, to which the 1889 Act led, from that prescribed by the Act for the University in St. Andrews, and to which the Commission attributes the main responsibility for the controversy and misunderstandings. No real solution, it is held, is possible while this constitutional structure, with its unworkable administrative organization, remains unchanged. Nevertheless, the survey revealed little reason for opinion in Dundee to be dissatisfied with the physical expansion of University College in the past five years, and, following a close analysis of the present situation, which takes full account of the intangible factors, the Commission rejects as firmly as Lord Cooper the proposal for a separate University in Dundee.

The reasoned argument which leads the Royal Commission to reject the idea of separation as neither necessary nor desirable is based on an examination of counter proposals which should at least mollify any disappointment which may be felt. Academic support for the proposal was almost non-existent; but the Commission, pointing out that it is an open question how far the sense of inferiority from which Dundee's local patriotism suffers is a survival from the unhappy past to which both Dundee and St. Andrews cling for different reasons, recognizes that the habit of mind which goes with this feeling is in some ways the most important element in the situation. Nevertheless, the Commission sees no case at all, on grounds of population, geography or communications, for placing a new University in Dundee, within fifteen miles of one University and ninety of three others, all distinguished in tradition and scholarship. Careful examination of the argument based on the industrial needs of Dundee revealed no serious discouragement in the field of applied science, even under the present unsatisfactory organization, while on the grounds of student numbers and the support of fundamental research the Commission is convinced that a new and vigorous academic development which would attract all the support the city can offer is possible within a remodelled University of St. Andrews without risk of discrimination against development in Dundee.

The major part of the report deals with the reorganization of the University to provide one governing body and one supreme authority in academic policy; it also includes a discussion of the changes in teaching policy which would become possible. In the early years of reorganization, it is emphasized that the frank acceptance and faithful implementation of detailed recommendations by an outside body offers the only prospect of agreement on academic policy. It is hoped that prompt government action where legislation is required will be followed by equally prompt and reasonable action in the academic sphere. Points of criticism will no doubt be found in matters of detail. It is not detail, however, but wise and early unification that is important, and the Tedder Report, offering a fair and just solution, provides the opportunity for a new start and for laying aside the dissensions of an unhappy half-century.

Broadly speaking, the type of union recommended is similar to, but rather closer than, that of the Durham and Newcastle Colleges. Subordinated to a single supreme authority, so constituted that it can be trusted to deal fairly with university education in both St. Andrews and Dundee, would be two College Councils, one for the new college in Dundee and one for the United College in St. Andrews. The heads of the two colleges would be designated 'provosts', and the principal of the University, and not the rector, would be chairman of the University Court, which would have the ultimate financial control of the whole University, and he should be provided with official accommodation in Dundee as well as his normal residence in St. Andrews. The Commission expresses the hope that if effect is given to its recommendations, the Queen would be pleased to allow the College in Dundee "to bear a name indicative of Royal favour", and it recommends that all possible steps should be taken to mark by outward and visible signs the new relationship of the University to Dundee and every opportunity taken of showing that Dundee as much as St. Andrews is heir to the traditions and resources of the University. The constitutional position of the Library Committee should be maintained, but with the added responsibility for the development of library facilities in Dundee. A reorientation of the Arts Departments in the new College in Dundee is recommended, and incorporation in the University, as part of the new College in Dundee, of the Dundee School of Economics. Postgraduate work in social sciences should also be developed in Dundee. No formal link between the Dundee Technical College and the University is proposed, and a first responsibility of the new College Council in Dundee would be an examination of the possibilities of development in engineering. The Commission dissents strongly from the view that problems arising from the duplication of teaching in Dundee and St. Andrews can be solved by making a head of department responsible for teaching given in both centres. Here, as in such recommendations as the removal of differences in the standards of admission for students, and of the discouragement by Scottish bursary regulations of those who wish themselves to bear the extra cost of coming from a distance to study in the University of St. Andrews, the Commission is doubtless seeking not only to avoid discords which divided loyalties and irrational disparities can cause, but also to afford the fullest possible opportunity for dissensions to die down and a wiser and more magnanimous spirit to close an unhappy chapter.

\section{SOUTH-EASTERN UNION OF SCIENTIFIC SOCIETIES}

\section{ANNUAL CONGRESS} $\mathrm{A}^{\mathrm{T}}$ the invitation of the Eastbourne Natural Eastern Union of Scientific Societies held its fiftyseventh annual congress at Eastbourne during April 24-27 under the presidency of James Fisher. The local committee was under the chairmanship of T. F. Rodd, with Miss M. A. Ash as local secretary.

At the 'young naturalists' evening' a wide range of questions were answered by a panel of experts and prizes given for the best questions asked. The winning questions wore those regarding the persistency of jackdaws in their attempts to acquire a nesting-site and the hatching of robin eggs after being found cold. Colour films were shown of bird life. In his presidential address to the Union, Mr. Fisher dealt with the population and distribution of land birds in 